\title{
Clinical Approach to Patients with Mastalgia in Breast Disease Outpatient Clinic
}

\author{
Sezgin Zeren ${ }^{1}$, Zülfü Bayhan ${ }^{1}$, Cengiz Koçak ${ }^{2}$
}

\begin{abstract}
Objective: The aim of this study was to report our approach and outcomes of patients applied to our breast disease policlinic with mastalgia.

Methods: The records of 877 patients presented with mastalgia to breast disease policlinic between April 2014 and January 2016 were examined retrospectively. Age, sex, body mass index (BMI), mammography breast imaging-reporting and data system score (BIRADS), ultrasonography evaluation, biopsy status, pathology results and operation procedures were investigated. Correlation between BIRADS score, age and BMI were analyzed.
\end{abstract}

Results: All of the patients were female and median age was 49,0 years. Ultrasound showed breast mass in 283 (32.3\%) patients and 165 (18.8\%) of these underwent fine needle aspiration or true cut biopsy. Only 14 (8.5\%) patients were diagnosed as malignant. Eight of the malignant cases had breast conserving surgery. Ages of the patients showed significant positive correlation with BIRADS classification values of the patients $(r=0.069, p=0.04)$. However, BMI values did not correlate with BIRADS classification values of the patients.

Conclusion: Mastalgia is a common symptom in women. In high risk patients for breast carcinoma, it should be investigated seriously. Both mammography and ultrasonography can be used at the same time for diagnoses. Especially in patients having dense breasts including young's, mammography alone cannot be satisfying for the evaluation. $J$ Clin Exp Invest 2016; 7 (1): 23-28

Key words: Mastalgia, breast policlinic, cancer, mammography

\section{Meme Hastalıkları Polikliniğine Mastalji Nedeni ile Başvuran Hastalara Klinik Yaklaşım}

\section{ÖZET}

Amaç: Bu çalışmanın amacı meme hastalıkları polikliniğimize mastalji nedeni ile başvuran hastalara yaklaşımımız ve sonuçların incelenmesidir.

Yöntemler: Nisan 2014- Ocak 2016 arasında meme hastalıkları polikliniğimize mastalji ile başvuran hastaların kayıtları retrospektif olarak analiz edildi. Yaş, cinsiyet, vücut kitle indeksi (VKI), meme görüntüleme ve raporlama veri sistem skorlaması (BIRADS), ultrasonografi durumu, biyopsi uygunluğu, patoloji sonuçları ve operasyon prosedürleri kayıt altına alındı ve analiz edildi.

Bulgular: Hastaların hepsi kadın olup, ortalama yaş 49,0 idi. Bunlardan $283(\% 32,3)$ tanesinde ultrasonografide memede kitle saptanmış. Akabinde $165(\% 18,8)$ tanesine ince iğne aspirasyon biyopsisi veya kalın iğne biyopsi uygulanmış. Sadece $14(\% 8,5)$ tanesi malign tanısı aldı. 8 tanesine meme koruyucu cerrahi yapıldı. BIRADS sınıflaması ve yaş arasında olumlu yönde korelasyon saptanmış olup $(r=0,069, p=0,04)$; BMI ve BIRADS sınıflaması arasında korelasyon saptanmadı.

Sonuç: Mastalji kadınlar arasında en sık görülen semptomlardan biridir. Meme kanseri açısından yüksek risk altında olanlar ciddi olarak incelenmelidir. Teşhis için aynı zamanda hem mamografi hem de ultrasonografi kullanılabilir. Başta genç hastalar olmak üzere özellikle yoğun meme dokusuna sahip olanlarda mamografi tek başına değerlendirme için yeterli değildir.

Anahtar kelimeler: Mastalji, meme polikliniği, kanser, mamografi

${ }^{1}$ Department of General Surgery, Faculty of Medicine, Dumlupinar University, Kutahya, Turkey

${ }^{2}$ Department of Pathology, Faculty of Medicine, Dumlupinar University, Kutahya, Turkey

Correspondence: Sezgin Zeren,

Department of General Surgery, Faculty of Medicine, Dumlupinar University, Turkey Email: sezginzeren@gmail.com

Received: 25.01.2016, Accepted: 15.03.2016

Copyright (C) JCEI / Journal of Clinical and Experimental Investigations 2016, All rights reserved 


\section{INTRODUCTION}

Breast cancer is the most common cancer type seen in woman around the worldwide [1]. In Turkey breast cancer is doubled in recent 20 years [2]. Because of these early diagnosis is significant. Early diagnosis of the breast cancer is the major factor decreasing both morbidity and mortality. Thus examination of breast by herself and attending breast screening program such as mammography annually are very important for women $[3,4]$.

Turkish Health of Ministry offers routine mammography every two years and physical examination per year after 40 years old [5]. In addition, Turkish Health of Ministry established breast disease policlinics in high volume centers.

The evident symptoms of the breast cancer are mastalgia and palpabl mass. Firstly physicians have to discriminate mastalgia is associated with benign or malignant conditions. Approximately $70 \%$ of women encountered with mastalgia in her life once a time [6].

Women generally apply to our breast disease policlinic with mastalgia. Detecting the underlying reason of mastalgia is essential. In this study we aim to investigate the patients admitted to our breast disease policlinic with mastalgia retrospectively. In addition to this we evaluated correlation between mammography breast 1maging-reporting and data system score (BIRADS), body mass index (BMI) and age.

\section{METHODS}

This retrospective study was performed in the Department of General Surgery of Dumlupinar University Evliya Celebi Research and Education Hospital, Turkey between April 2014 and January 2016. The patients identities and personal information were not shared in this article. Data of the 1265 patients were evaluated. The patients having cyclic mastalgia, granulomatous mastitis, under 18 years old, palpabl mass with no complaint of mastalgia and previous breast surgery history were excluded from study. Finally we included 877 patients in regard to anamnesis, physical examination, bilateral mammography and or ultrasonography respectively. Age, sex, BMI, BIRADS, ultrasonography evaluation, biopsy status, pathology results and operation procedures were investigated.

\section{Statistical analysis}

Statistical analyses were performed using GraphPad Prism version 6.05 (GraphPad Software, Inc., CA,
USA). All variables were tested for normality using Kolmogorov-Smirnov test. Since all variables were not normally distributed, data were expressed as median and interquartile range (IQR). The correlations between age, BMI, and BIRADS classification values of the patients were analyzed using Spearman's correlation analysis. A P value less than 0.05 was considered statistically significant

\section{RESULTS}

The demographic and clinical data of the 877 patients are represented in Table 1 and 2. All of the patients were female and median age was 49.0 years. The number of patients who had a breast mass on their ultrasonography is $283(32.3 \%)$ and $165(18.8 \%)$ of these underwent fine needle aspiration or true cut biopsy. Because of the higher probability of malignancy features in ultrasonography and as the surgeons' preference segmentar mastectomy procedure was performed in 7 patients without biopsy. Only 14 (8.5\%) patients were diagnosed as malignant. All malignant patients were undergone to surgery. Modified radical mastectomy was chosen as a surgical treatment option in 6 patients due to advanced stage and patients' request and 8 patients underwent breast conserving surgery including sentinel lymph node biopsy.

Table 1. Demographic data and BIRADS classification values of the patients $(n=877)$

\begin{tabular}{lcc}
\hline & Median & $\begin{array}{c}\text { Interquartile } \\
\text { Ranges (IQRs) }\end{array}$ \\
\hline Age, years & 49.0 & $38.0-59.0$ \\
BMI, $\mathrm{kg} / \mathrm{m}^{2}$ & 30.10 & $25.20-33.50$ \\
BIRADS Classification & 1.0 & $0.0-1.0$ \\
\hline
\end{tabular}

BMI: Body mass index, BIRADS: Breast Imaging-Reporting and Data System

Box and whisker plot of BIRADS classification values in the patients are represented in Figure 1. Percentage distribution graphs of clinical data of the patients are represented in Figure 2 evidently. In addition to this, we investigated the correlation between BIRADS classification, BMI and age

BMI values were not correlated with BIRADS classification values of the patients $(r=0.015, p=0.666$, Fig. 3). However, ages of the patients showed significant positive correlation with BIRADS classification values of the patients $(r=0.069, p=0.04$, Figure 3$)$. 
Table 2. Clinical data of the patients $(n=877)$

\begin{tabular}{lll}
\hline & $\mathbf{n}$ & $\mathbf{\%}$ \\
\hline Breast mass with USG & 283 & 32.3 \\
Biopsy & 165 & 18.8 \\
$\begin{array}{l}\text { Pathology result } \\
\quad \text { Benign }\end{array}$ & 151 & 91.5 \\
$\quad$ Malign & 14 & 8.5 \\
\hline Type of malignity & & \\
$\quad$ Invasive ductal carcinoma & 11 & 78.6 \\
$\quad$ Lobular carcinoma & 2 & 14.3 \\
$\quad$ Ductal carcinoma in situ & 1 & 7.1 \\
\hline Surgical operation & 21 & 2.4 \\
Surgical operation type & & \\
$\quad$ Segmental mastectomy & 7 & 33.3 \\
$\quad$ Sentinel lymph node surgery & 8 & 38.1 \\
\hline$\quad$ Modified radical mastectomy & 6 & 28.6 \\
\hline USG: Ultrasonography & & \\
\hline
\end{tabular}

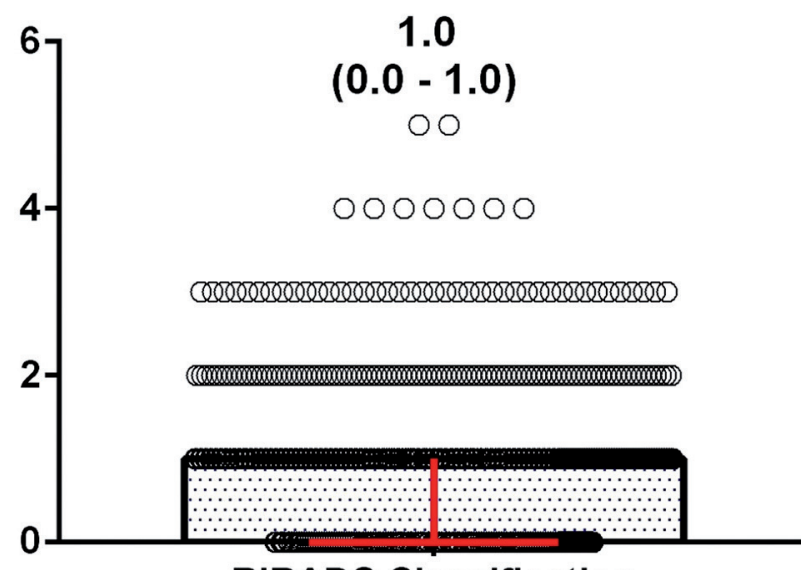

BIRADS Classification

Figure 1. Box and whisker plot of BIRADS classification values in the patients.
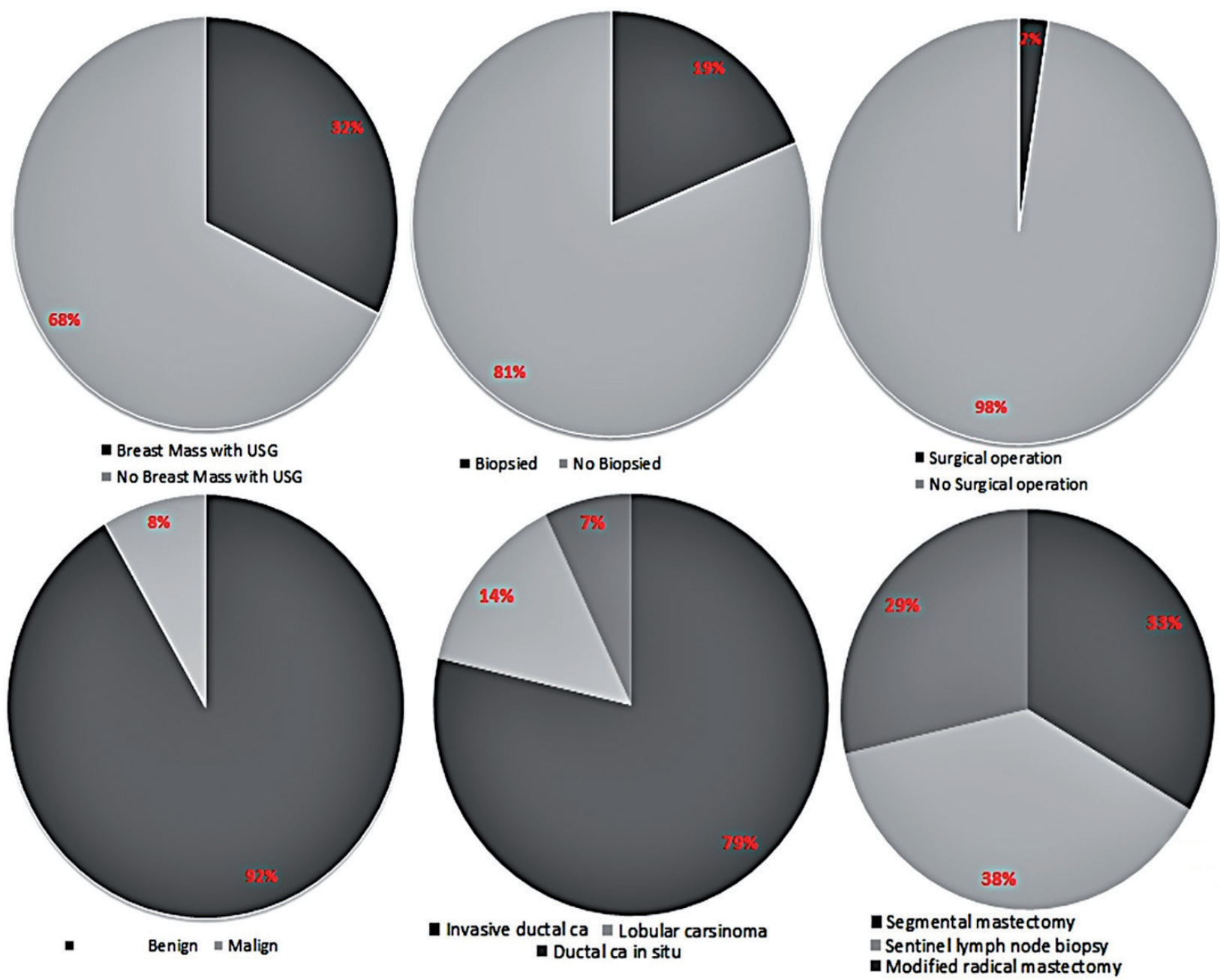

Figure 2. Percentage distribution graphs of clinical data of the patients. 

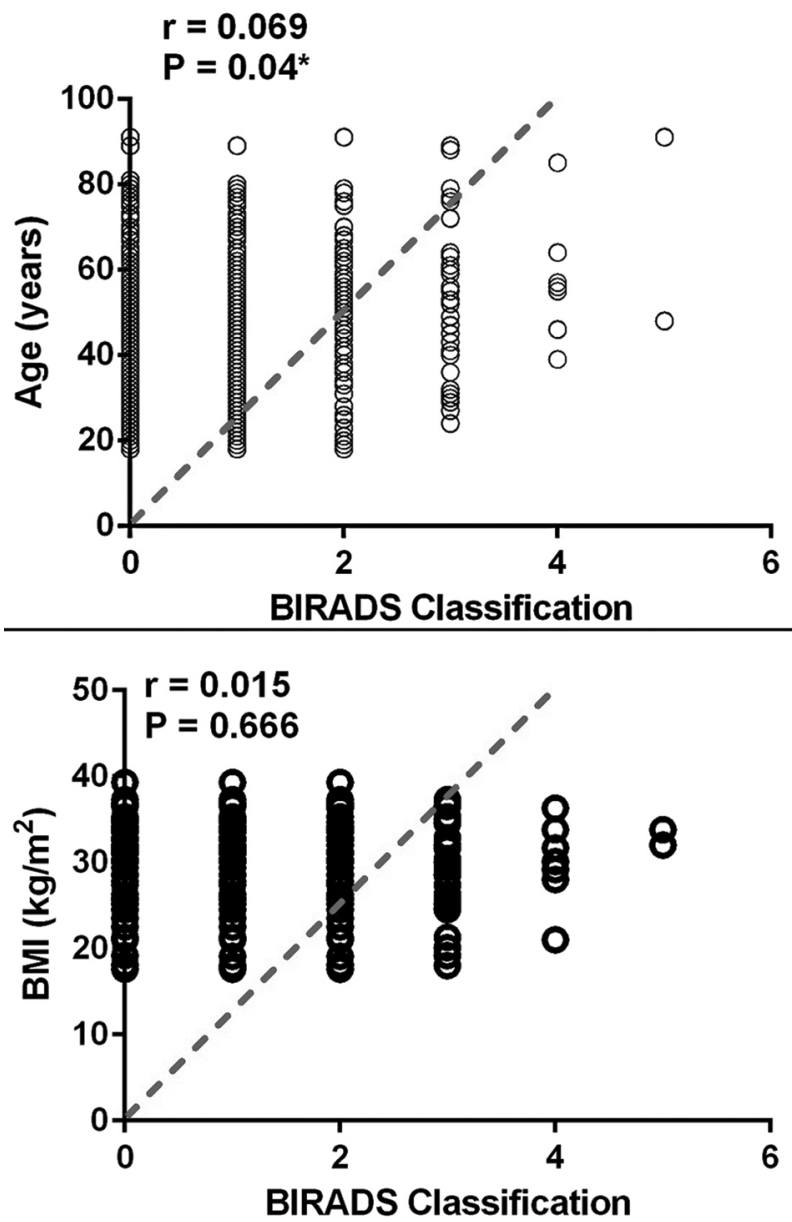

Figure 3. Spearman's correlation analysis between age, body mass index, and BIRADS classification values of the patients.

\section{DISCUSSION}

Mastalgia is a very common disorder that affects quality of the life in women directly. Nowadays the people's using internet and media greatly, resulted that mastalgia is associated with breast cancer. However only breast pain is not a major symptom of breast cancer. The possibility of breast cancer with a symptom of mastalgia is very low [7]. In our study totally 1265 patients applied to our breast policlinic but only 14 of them diagnosed as breast cancer.

Especially Turkish Ministry of Health opened cancer screening centers (KETEM) for breast cancer. The basic aim is to screen all women in society and solve easy health problems including mastalgia in the first step health centers. In a recent study it was offered that mastalgia should be managed in primary care [8]. However, approximately totally of the our patients were evaluated in KETEM and referred to us. Therefore, we thought that the evaluation process in KETEM should be reviewed again because so much patients referred to our breast policlinic with mastalgia orderly. Additionally the women might be educated for self-examination more consciously. In an study by Aker et al [5] claimed that self-examination of breast for detecting masses is very important. We also recommend periodic self-examination to our patients and educate them for self-breast examination.

All patients admitted to our breast policlinic were examined. The ones above 40 years old were screened with mammography initially. Ultrasonography is not performed to all patients. According to mammography and examination results, we decide whether ultrasonography is necessary. In the literature mammography screening and ultrasonography using is still controversial. This is still dilemma for surgeons. Wise J. [9] investigated that according to new guidelines from the American Cancer Society breast cancer screening should start at the age of 45 and women over 55 years can be screened every two years instead of every year with an averaged risk of malignancy. In another study by Chang et al. [10] suggested that combined radiologic scanning tests were the best ones. Especially mammography and ultrasonography combination was great for detecting lesions [11]. Constanza [12] claimed that mammography screening became obsolete. It is a very assertive claim. In this study nearly total of the patients went undergone to mammography imaging. When we evaluated the results with BIRADS, some of them were scored as BIRADS 0 which means there is a need of additional imaging. Box and whisker plot of BIRADS classification values (Figure 1) indicate this condition well. We evaluated patients for their high risk cancer status. In case of a high risk for malignancy then we evaluate with breast ultrasonography. But if the patient is under 35 without a high breast cancer risk, we call these patients for physical examination control periodically. New techniques were developed for malignant lesion detection in breast tissue. Balcik A. et al. [13] used sonoelastography for distinguishing benign and malignant lesions. They found that sonoelastography was better than conventional ultrasonography for malignant lesion detection in breast tissue [14].

Mastalgia decreases the quality of the life in women population. In the literature there are medical treatments for mastalgia including prime rose oil, tamoxifen, danazol, gamma linolenic acid and fructus 
agni casti. On the other hand these treatment modalities are still controversial [15-17]. In our breast policlinic we generally avoid medication. Especially we use hormonal medicines rarely.

Our histopathology results were parallel to literature [18]. Most of the malignant cases were invasive ductal carcinoma $(78.6 \%)$ and rarely lobuler carcinoma and in situ ductal carcinoma.

Obesity is associated with some of the cancer types. One of them is breast cancer. Therefore, we investigated BMI of the patients too. Renehan et al [19] estimated that for each $5 \mathrm{~kg} / \mathrm{m}^{2}$ increase in BMI the risk of breast cancer was increased by $12 \%$. In our malignant patients, we could observe higher BMI easily. However, our malignant case number data is not sufficient to perform a statistical analysis. We thought that, there may be a correlation between mammography BIRADS score and BMI or age. We did not see a correlation between BMI and mammography BIRADS score system. On the other hand, there is a significant correlation between mammography BIRADS score system and age absolutely (Figure 2 and Figure 3). In high density breast tissues mammography are not too sensitive [20]. In younger patients the density of breasts increase, thus only mammography is not enough for evaluation. We should add another imaging modality. In our study we also found that some of the young patients' mammography BIRADS score were 0 , which means necessity of additional imaging. These patients were also underwent to ultrasonography.

To the best of our knowledge this study is the first evaluating a correlation between BMI, age and mammography BIRADS score. Besides this is the first to find out that there is correlation between age and mammography BIRADS score system.

Major limitation of our study is it's being retrospective nature. Further prospective studies are needed for evaluating mastalgia definitely.

In conclusion, this original research investigated the patients who applied to breast policlinic with mastalgia retrospectively. The ages of the patients showed significant positive correlation with BIRADS classification values of the patients in our study. However, BMI values were not correlated with BIRADS classification values of the patients. Mastalgia should be evaluated carefully in patients both with mammography and ultrasonography. Evaluating only with mammography is inadequate. Besides this in the patients who have higher BMI values may have non-palpable masses, in case of this fine needle aspiration or truecut biopsy should not be avoided.

Declaration of Conflicting Interests: The authors declare that they have no conflict of interest.

Financial Disclosure: No financial support was received.

\section{REFERENCES}

1. Eser S, Yakut C, Ozdemir R, et al. Cancer incidence rates in Turkey in 2006: A detailed registry based estimation. Asian Pac J Cancer Prev 2006;11:1731-1739.

2. Ozmen V. Turkiye'de meme kanseri: Klinik ve histopatolojik özellikler (13.240 olgunun analizi). J Breast Health 2014;10:98-105.

3. Parvani Z. Breast self-examination; Breast awareness and practices of systematic review. Professional Med J 2011;18:336-339.

4. Elmore JG, Armstrong K, Lehman CD, Fletcher SW. Screening for breast cancer. JAMA 2005;293:1245-1256.

5. Aker S, Oz H, Tuncel EK. Practice of Breast Cancer Early Diagnosis Methods among Women Living in Samsun, and Factors Associated with This Practice. J Breast Health 2015;11:115-122.

6. Kızılkaya MC, Erozgen F, Kocakuşak A, et al. Mastalgia in daily practice. Breast Health 2013;9:191-194.

7. Ölçüçüoğlu E, Yılmaz G. Mastodynia: is imaging necessary in young patients? Ulus Cerrahi Derg 2013;29:17-19.

8. Joyce DP, Alamiri J, Lowery AJ, et al. Breast clinic referrals: can mastalgia be managed in primary care? Ir J Med Sci. 2014;183:639-642.

9. Wise J. Start mammography at age 45, US guideline recommends. BMJ 2015:20;351:h5570.

10. Chang TH, Hsu HH, Chou YC, et al. The Values of combined and sub stratified imaging scores with ultrasonography and mammography in breast cancer subtypes. PLoS One 2015;10:e0145390.

11. Özan E, Köroğlu M, Parlak E, et al. Role of breast ultrasound in patients with negative mammogram presenting with breast pain without a palpable lump. J Clin Anal Med 2015;6:50-52.

12. Costanza ME. Has screening mammography become obsolete? Curr Oncol 2015;22:328-331.

13. Balçık A, Polat AV, Bayrak IK, Polat AK. Efficacy of sonoelastography in distinguishing benign from malignant breast masses. J Breast Health 2016;12:37-43.

14. Dinç T, Dikmen K, Coşkun F. Mastalji yakinmasi ile polikliniğe müracaat eden hastalarda meme ultrasonografi bulgulari ve risk faktörlerinin önemi. Gazi Medical Journal 2013;24:127-129.

15. Kataria K, Dhar A, Srivastava A, et al. A systematic review of current understanding and management of mastalgia. Indian J Surg. 2014;76:217-222. 
16. Dinç T, Coşkun F. Comparison of fructus agni casti and flurbiprofen in the treatment of cyclic mastalgia in premenopausal women. Ulus Cerrahi Der. 2014;30:34-38.

17. JA. Files, VM. Miller, SS. Cha, Pruthi S. Effects of different hormone therapies on breast pain in recently postmenopausal women: findings from the Mayo Clinic KEEPS breast pain ancillary study. J Womens Health (Larchmt) 2014;23:801-805.

18. Abd El Moneim HM, Zaghloul NM. Expression of e-cadherin, n-cadherin and snail and their correlation with clinicopathological variants: an immunohistochemical study of132 invasive ductal breast carcinomas in Egypt. Clinics (Sao Paulo) 2011;66:1765-1771.

19. Renehan AG, Tyson M, Egger M, et al. Body-mass index and incidence of cancer: a systematic review and metaanalysis of prospective observational studies. Lancet 2008;371:569-578.

20. JT. Schousboe, K.Kerlikowske, A.Loh, Cummings SR. Personalizing Mammography by Breast Density and Other Risk Factors for Breast Cancer: Analysis of Health Benefits and Cost-Effectiveness. Ann Intern Med 2011;155:10-20. 